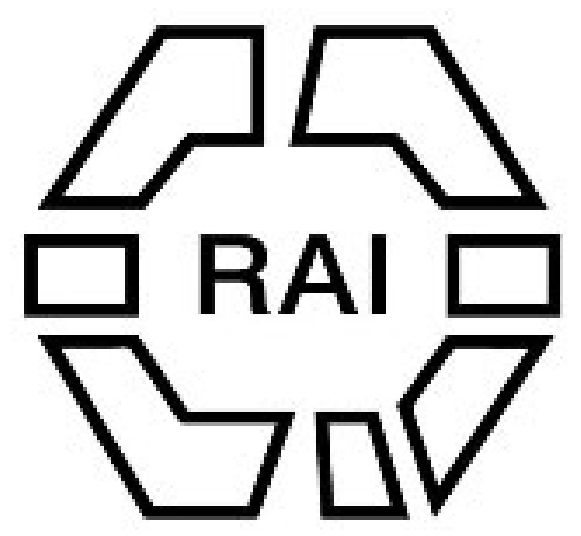

Royal Marriages and Matrilineal Descent.

Author(s): Margaret Murray

Source: The Journal of the Royal Anthropological Institute of Great Britain and Ireland, Vol. 45 (Jul. - Dec., 1915), pp. 307-325

Published by: Royal Anthropological Institute of Great Britain and Ireland

Stable URL: http://www.jstor.org/stable/2843479

Accessed: 28/06/2014 08:50

Your use of the JSTOR archive indicates your acceptance of the Terms \& Conditions of Use, available at http://www.jstor.org/page/info/about/policies/terms.jsp

JSTOR is a not-for-profit service that helps scholars, researchers, and students discover, use, and build upon a wide range of content in a trusted digital archive. We use information technology and tools to increase productivity and facilitate new forms of scholarship. For more information about JSTOR, please contact support@jstor.org. 


\section{ROYAL MARRIAGES AND MATRILINEAL DESCENT.}

\section{By Margaret Murray.}

I AM not concerned in this paper with the origin of Matrilineal Descent, nor with the reasons for the custom. I merely wish to point out that it occurs among peoples whom we are accustomed to look upon as civilised, and that it is therefore of considerable importance for the right understanding of certain points in ancient. history, which are often slurred over or looked upon as too obscure for elucidation.

It is obvious that the reckoning of descent in either the male or female line can be of value only when there is something to inherit. Land is naturally considered as the most important of all heritages, and the chief land-inheritance is the kingdom. Therefore it is among noble, and particularly royal, families that we expect to find genealogies carefully kept, and it is in these genealogies that we must look for the records of female inheritance.

The working of the law of female inheritance in modern times is found in the kingdom of Travancore. (Succession in the family of the Raja of Cochin on the Malabar Coast is also governed in the same way.) I quote from Sir Charles Aitchison's Treaties, ${ }^{1}$ which is the authoritative work on the subject.

"The laws which govern the succession to the State of Travancore are very peculiar. The descent, according to the usages of the Nairs of the Western Coast, is in the female line. Thus on the death of the Raja the sovereignty passes not to his sons, who can in no case inherit, but to his uterine brothers if he has any. Failing these, or on their demise, it passes to his sister's sons, or to his sister's daughter's sons, and so on. Hence it follows that the only adoptions which are performed by the Rajas of Travancore are not of males to supply the place of sons of their own body, but of females through whom the line must be continued. Any failure of the direct female descent requires the selection and adoption of two or more females from the immediate relatives of the family who reside at certain places in Travancore. The females so adopted are designated the Tumbrattees or Ranis of Attingah, and by the laws and usages of Travancore are assigned a distinguished rank as alone entitled to give heirs to the state, and enjoy many important privileges. Such an adoption occurred in 1788, when two sisters were selected and adopted as Ranis of Attingah. The younger sister died after giving birth to a female child which also died. From the elder sister the present family of

${ }^{1}$ Aitchison, Treaties, Engagements and Sunnuds, v, p. 422 seq., ed. 1876. 
Travancore are descended, the late Raja being the grandson (daughter's son), the present the great grandson (daughter's daughter's son). In 1857 the line of Travancore was again threatened with eventual extinction. The sister of the late Raja (granddaughter-daughter's daughter-of the elder of the two sisters adopted in 1788) left five children, four sons, the second of whom is the present chief, and one daughter. The daughter died suddenly, leaving two sons. The Tumbrattees of Attingah thus became extinct, and although the state after the death of the Raja would devolve successively on his four nephews and his two grandnephews, the line, unless recruited by the adoption of Tumbrattees as before, would have expired with them. Under these circumstances the late Raja intimated to the Resident that, in strict conformity with former usage and precedent, he proposed to bring in two, the most eligible female members from among his relations, as senior and junior Ranis. Two ladies were accordingly adopted with the sanction of the British Government."

With living examples before us it is possible to follow the working of the custom of inheritance in the female line in ancient times, when the laws against consanguinity in marriage were not so strict as at the present day. It must be fairly obvious that when property descended through the woman, the man who could obtain possession of the heiress obtained also possession of the property for himself during his lifetime and for his children after his death. The natural protector of the woman and the natural owner of the property would be her nearest male relative. Hence the custom in ancient times of consanguineous marriages in every degree of close relationship. As an example familiar to us all of succession to the throne by right of marriage with the heiress, I would cite the play of "Hamlet," where the murdered king is succeeded, not by his son, though of an age to reign, but by the new husband of the queen. The hurried marriage after the first husband's death was due to the eagerness of the murderer to seize the crown; the people accepted the new king, never looking upon him as a usurper; the marriage aroused no indignation or horror among them, and the king's only fear was the discovery of the murder by which he had cleared his way to the hand of the heiress and the possession of the throne.

I am concerned in this paper with pointing out that where in ancient history we find consanguineous marriages in the closest possible degrees of relationship, we are not always dealing with records of licentiousness and vice, as the historians, ancient and modern, would have us believe, but with a system of matrilineal descent and female inheritance preserved in a royal family. Royalty being more strictly bound by ancient tradition than the people, such a custom would be observed in the royal family long after it had vanished from the rest of the kingdom. It is therefore only to be expected that the system should be completely misunderstood and its results often held in utter abhorrence by the historians who have handed down the accounts to us, especially by those who were either not contemporary with the events they related, or were observing the customs of a foreign country. This is to my mind so much the case that I am convinced that 
wherever marriages are found to be closely consanguineous, there one must look for inheritance in the female line, and the genealogy must be carefully scanned with this idea in mind, remembering that the man's descent is not necessarily of any importance; it is by marriage and not by inheritance that he lays claim to the throne. Therefore it is the woman and her maternal genealogy which must be followed.

To prove my point I will take only three nations, the Egyptian, the Jewish, and the Roman. The custom occurred in most of the nations of antiquity without doubt, but these three will be sufficient.

In Egyptian history I propose to take only two periods, the early New Kingdom, i.e., about 1600 B.c., and the Ptolemaic era ; for at both these periods the records are more complete than at any other. Chronologically the Biblical history should follow on between these two Egyptian periods, but. I prefer to divide the subject geographically. In Egypt one sees very clearly that the king succeeded by right of marriage only; so much so that it is possible to put the principle of female inheritance shortly thus : the queen is queen by right of birth, the king is king by right of marriage. The resulting intermarriages can also be expressed by the Kalmuck proverb, "Great people and dogs know no relationship." Though this is, perhaps, clearer in Egypt than elsewhere, it can, I think, be proved in the House of Judah, and among the Claudian Emperors.

\section{Egypt-NeW Kingdom.}

Amongst the Pharaohs of the early New Kingdom the principle of matrilineal descent is very strongly marked, and as I have said before, marriages in every degree of affinity are found. I do not propose to go into any detail of proof here, as Egyptian history is still a highly technical subject, but I take eight successive queens who lived in the seventeenth and sixteenth centuries B.c. It is acknowledged by all Egyptologists that when a queen has the titles "King's sister, king's wife," those epithets apply to the relationship between her and the king with whom she is mentioned, but when the title "King's daughter" occurs at the same time, it is usual to say that it applies to the previous king. My contention is that such titles apply to the king with whom the queen is associated in the inscription.

If these titles are taken as I propose to take them, it would show that when a queen is daughter, sister and wife to the king, the previous queen was both mother and wife of the same man, i.e., the reigning queen is daughter to the king because her mother was his wife, and she is also his sister because she was born of the same mother as himseif.

It will be noted that the king might have any number of wives at the same time, as he appeared to marry all the heiresses in order to secure his own position and prevent claimants to the throne; but a queen could only have one husband at a time, though any number consecutively, as her husband was the rightful ruler by reason of his marriage with her. 
The relationships are so complicated that it is impossible to make a genealogical table in the ordinary way. The genealogy of Aahmes I. appears quite simple when written out thus-

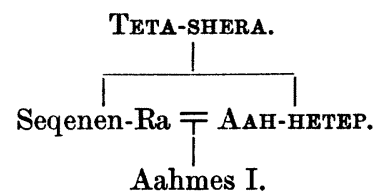

but Seqenen-Ra was the father, brother, and husband of Aah-hetep, who on his death married the son, Aahmes I., whom she had borne to him. I have therefore expressed the marriages by a different method, though the filiation of the kings is shown in the usual way. The relationships of the queens to the respective kings is given after the name of each king.

\section{EGYPTIAN QUEENS.}

Women's names in capitals.

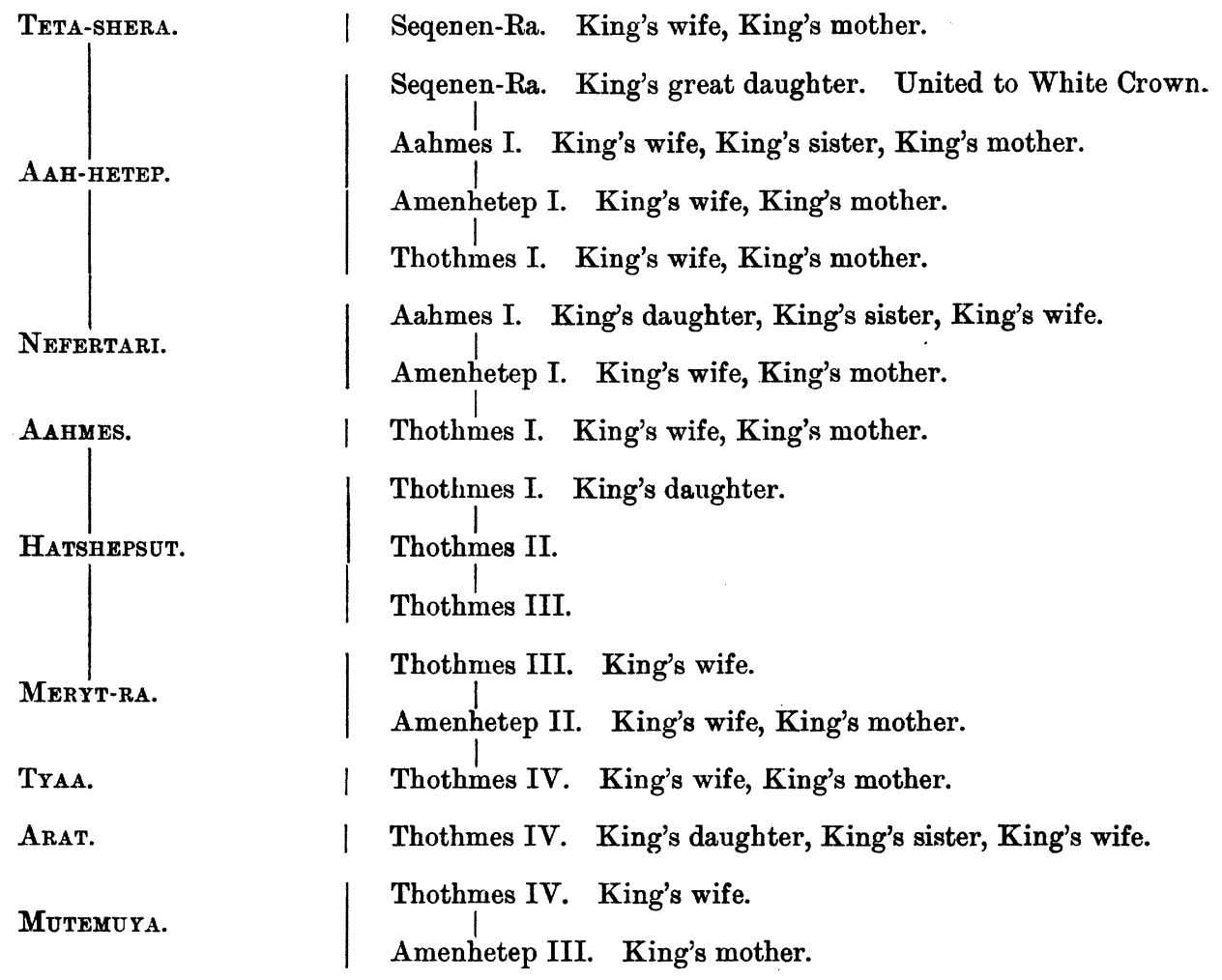

The position of Hatshepsut is confused, as she reigned alone and used the titles of a king for herself. She was certainly the daughter of Thothmes I. and was associated with him as a queen, which leads one to suppose that she was married to him. She was apparently the wife of Thothmes II., and it seems likely that she was married to Thothmes III. also, for her daughter Nefru-ra, when represented between Hatshepsut and Thothmes III., is called King's daughter. 


\section{Egyptian History : Ptolemaic Period.}

There is always a certain difficulty in tracing the beginning of a genealogy, and the Ptolemies are no exception. The fact that the father of Lagos was unknown even to his grandson, Ptolemy Soter, is a proof that the male descent was not of great importance. The theory that the genealogy of Berenice was invented in later times in order to prove that brother-and-sister marriage was practised by the founder of the dynasty, cannot be maintained. Marriages of relatives closely allied by blood are, as I have mentioned before, the custom in certain stages of society only when there is some material advantage to be gained by such a union, i.e., when the advantage is gained by inheritance by or through women.

A glance at the genealogies of the Ptolemies in the female line shows that they derive from three main stocks. The first is from Cassander, the second from his brother Antipater, the third from the Persian satrap of Phrygia, Artabazos III., one of whose daughters was considered a fit match for Alexander himself. When the female line of Cassander ends, the reigning Ptolemy marries the heiress of the eldest daughter of Antipater, he himself being descended on the mother's side from a younger daughter. There are, unfortunately, no records of the marriages of Antipater, and consequently no proof that his three daughters were born of one mother, though the difference in age lends probability to the theory that the two younger were half-sisters of Phila. On the failure of the female line of Antipater, a marriage is effected between Ptolemy Epiphanes and Cleopatra I., the heiress in direct matrilineal descent from Artabazos III., an ancestor from whom all the Ptolemies descended by the marriage of Lagos with Arsinoe, daughter of the Persian satrap. By accepting this theory of the descent of the throne in the direct female line, the closely consanguineous marriages are explained, especially when it is remembered that legitimacy and illegitimacy were ideas of a later growth, and that the daughter of a queen, by whatever husband, was the heiress of the crown. It accounts also for the fact that when the two brothers, Philometor I. and Euergetes II., reigned together, they were associated on the throne with their sister in such way as to make it fairly certain that they were both married to her. On the death of Philometor, Euergetes ensured his position by marrying the next heiress as well.

In the troubled times of the tenth and eleventh Ptolemies, Soter II. (Lathyrus) and Alexander I., female inheritance throws light on some of the problems. The family squabbles, which in royal families lead to wars, were due to the question as to who was the rightful king, the husband of the queen or the husband of the next heiress.

The doubtful filiation of Cleopatra V. is the weakest link in the chain of the genealogy. She claimed to be the sister of Auletes; and as brother-and-sister marriage was not practised for mere wantonness, but for certain definite reasons, her mother must have been of the royal line, possibly Cleopatra IV. The filiation 


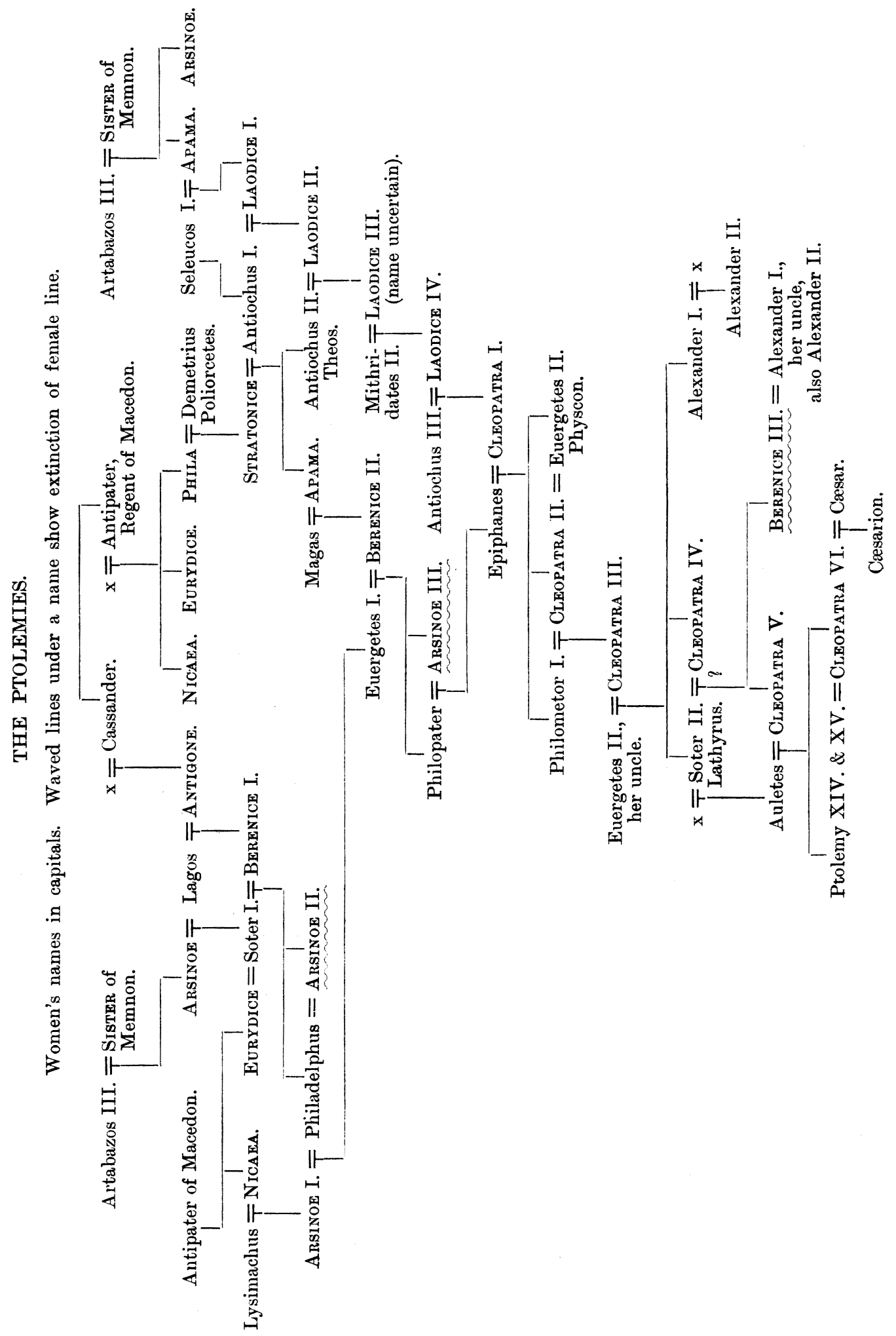


of Cleopatra the Great must also be accepted in view of her successive marriages with her two brothers; for the theory of the descent of the throne by and through women can alone explain her further marriages also. Cæsar, by conquest ruler of Egypt, legitimised his position by marrying the queen. Antony became king of Egypt by the same means; his marriage with Octavia was binding in Rome, but in Egypt the queen was his lawful wife, and Octavia, who was not of the Egyptian royal line, took a second place. The Roman historians, imbued as they were with the idea of monogamy, utterly failed to understand the position. With the death of Cleopatra Egypt ceased to be a kingdom and became the private property of the Emperors of Rome, and was then governed by Roman laws of inheritance and marriage. Cleopatra's son by Cæsar was killed, her children by Antony were illegitimate according to Roman law, he having a wife at the time of his marriage; but Zenobia claimed the throne of Egypt, and was for a short period successful in that claim, by right of descent from Cleopatra.

\section{Bible History.}

In the Bible records, the genealogies and the early history have been so rigorously excised by later editors that it is often difficult, if not impossible, to follow them. [As an example of such excision, I would draw attention to I Chronicles vii, 14, which begins the genealogy of the tribe of Manasseh: "The sons of Manasseh: Ashriel whom she bare," where it is obvious that a woman's name has been cut out, for as the words stand, "she" refers to Manasseh; which, as Euclid says, is absurd ${ }^{1}$.] The custom of female inheritance in historic times appears to have been followed in the southern country only, where we have to do with the tribes of Judah and Benjamin; in the north, the kingdom of Israel went to any man who could take or hold it by force of arms.

\section{THE HOUSE OF JUDAH.}

Women's names in capitals.

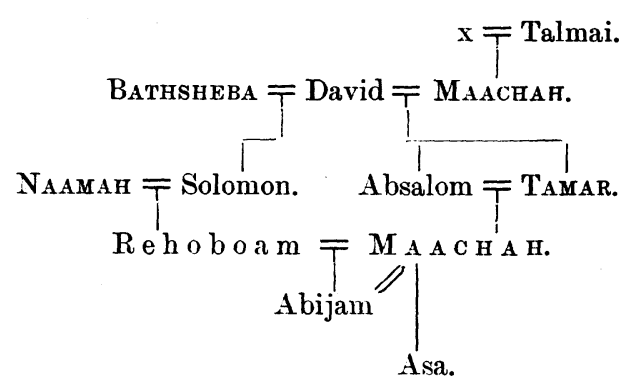

In the account of the early kings, kingship appears to have been dependent on two facts: (1) appointment by the chief sacerdotal authority or by the reigning monarch; (2) marriage with the heiress. The history of Saul is so fragmentary that

1 The verb is in the feminine in the Hebrew without a pronoun. 
although we know of his appointment by Samuel, we know only the name of his wife and not her genealogy beyond her father's name. But when we come to David we are on firmer ground. David was appointed and anointed king by Samuel, and in connection with this event Josephus ${ }^{1}$ makes an interesting remark : "The Divine Power departed from Saul and removed to David, who, upon this removal of the Divine Spirit to him, began to prophesy." Here I think we see the reason for the appointment of a king: by this means the Divine Spirit was handed on to the successor that he might be the receptacle of the deity, in other words the incarnate god. This idea remains down to our own times among the Shilluk at Fashoda. ${ }^{2}$ This was what may be called the spiritual side of kingship; the actual rule was obtained by marriage with the heiress. In the case of David the appointing and anointing came first, then came the marriage with Michal the daughter of Saul; and it was after this marriage, when David was thus the acknowledged heir, that Saul's hatred grew virulent: "and Saul was yet the more afraid of David ; and Saul became David's enemy continually." It is necessary to remember that Saul had four sons, Jonathan, Abinadab, Melchi-shua, and Ishbosheth; of these, the first three are never looked upon as having a claim on the throne, which shows that inheritance in the male line was not yet established in Judah and Benjamin. As for Abner's ill-starred attempt to put Ishbosheth on the throne after Saul's death, it is noticeable that the great mass of his forces were drawn from the northerly tribes.

There is some discrepancy in the Biblical account of Michal, the daughter of Saul. In I Samuel xviii, 17-21, two daughters, Merab and Michal, are mentioned ; Merab is said to have been the elder and to have married Adriel the Meholathite; while in II Samuel xxi, 8, there is mention of the "five sons of Michal, the daughter of Saul, whom she bare to Adriel the son of Barzillai the Meholathite." Josephus speaks of only one daughter of Saul, namely Michal; therefore it seems likely that there was but the one daughter, who was married first to Adriel, by whom she had sons only, and then to David, by whom she had no children.

When David was driven out by Saul and was a wanderer with but few followers, Saul gave Michal in marriage to Phalti the son of Laish, hoping perhaps to destroy David's claim to the throne thereby. That David recognised this danger is shown by his insisting, as one of the terms of peace with Ishbosheth and Abner, that Michal should be brought back to him. As Michal had no daughters, a new heiress had either to be found in a collateral branch, or adopted as in the case of the Rajas of Travancore and Cochin. This heiress appears to have been Tamar, David's daughter by Maachah, daughter of Talmai, king of Geshur. Matrilineal descent is to my mind the only explanation of two episodes, the first of which is given in II Samuel xiii, where Amnon, David's first-born son, fell in love with Tamar. It would seem that primogeniture in the male line was already recognised among some part at least of the people, though not in the royal family;

1 Josephus, Antiquities of the Jews, viii, 2.

2 Seligmann, Report of Wellcome Tropical Research Laboratories, vol. B. 
for the three sons of David who made attempts on the throne did so in the order of their birth; Daniel the second son, who is also called Chelub, is merely a name, and possibly died young. Tamar's words to Amnon show. that brother-and-sister marriage was allowable: "Now, therefore, I pray thee, speak unto the king, for he will not withhold me from thee." It is difficult to see why this episode should have been preserved when others equally scandalous have probably been omitted. In itself the provocation was not sufficient for Absalom to run the risk of outlawry by murdering Amnon; but if marriage with Tamar carried the kingdom with it, and Amnon had established the prior right to her, then Absalom, the next in age and of royal blood on both sides, cleared his way to the throne by murder. Tamar had taken refuge with Absalom, who was her full brother ; and according to Josephus $^{2}$ they were married. Josephus does not speak of the marriage in so many words, but mentions the daughter of Absalom by Tamar.

The second episode is that of Abishag the Shunammite, as given in I Kings, i and ii. The position of this woman can only be made clear by seeing in her the next heiress in case of the death of Tamar or Tamar's daughter. First, she was "sought for throughout all the coasts of Israel"; hardly a likely proceeding if all that was wanted was a pretty girl to take care of the old king, his wife Bathsheba being still alive; but extremely likely if the genealogies of possible claimants had to be scrutinised; then, it is distinctly said it was a purely ceremonial marriage between David and Abishag. When David was almost in extremis, Adonijah, his eldest surviving son, got himself proclaimed king by the help of Abiathar, though not appointed and apparently not married. The more wily Nathan, ably assisted by Bathsheba, persuaded the dying king to appoint Solomon as his successor, and Solomon was at once proclaimed and publicly anointed. This news so terrified Adonijah as he sat feasting with his adherents that be fled to the altar for sanctuary, and there remained till Solomon swore to spare his life. Adonijah's attempt to secure the throne by right of primogeniture having failed, he then reverted to the custom in vogue in the royal family. He persuaded Bathsheba to ask Solomon to give Abishag to him to wife: and he artfully suggested that as the king could not refuse any request to his mother, she should induce him to promise to perform whatever she asked before knowing her request. Bathsheba faithfully fulfilled her part; she said, "I desire one small petition of thee; I pray thee, say me not nay. And the king said unto her, Ask on, my mother: for I will not say thee nay. And she said, Let Abishag the Shunammite be given Adonijah thy brother to wife." Now note Solomon's significant answer and action: "And king Solomon answered and said unto his mother, And why dost thou ask Abishag the Shunammite for Adonijah ? ask for him the kingdom also ; for he is mine elder brother. . . . Then king Solomon sware by the Lord, saying, God do so to me, and more also, if Adonijah have not spoken this word against his own life.

1 Josephus, Antiquities of the Jews, Book VII, ch. viii, 1.

2 Id. ib., Book VIII, ch. $\mathrm{x}, 1$.

VOL. XLV. 
Now therefore, as the Lord liveth ... Adonijah shall be put to death this day. And king Solomon sent by the hand of Benaiah the son of Jehoiada; and he fell upon him that he died." Solqmon's sudden outburst of fury at the proposed marriage and the breaking of his solemn oath to spare Adonijah can be entirely accounted for by the theory that he himself was as yet king only by appointment and anointing, and not by marriage, and that Adonijah's daring proposal was to marry one of the heiresses and thus claim the throne.

Solomon's matrimonial alliances were so numerous as to cause grave scandal to the later. editors of the history, and the record appears to have been expunged with great thoroughness; so much so that, with the exception of the marriage with Pharaoh's daughter, the wives are only mentioned as the reason for his apostasy from the state religion. The Arab historian Masoudi, however, takes it for granted that Solomon married the Queen of Sheba, and records as a matter of history that Solomon possessed the Yemen (or Sheba) for twenty-three years, and that after his death the kingdom reverted to the family of Himyar. This suggests that Solomon was king of Sheba by right of marriage.

But though we have no detailed records of Solomon's marriages, we have a very marked instance of matrilineal descent among his immediate successors; and seeing that the custom of female inheritance occurs both before and after his reign, we are justified in believing that he followed the same custom.

Rehoboam, Solomon's son and immediate successor, married, according to II Chronicles xi, 20, 21, Maachah the daughter of Absalom, "and Rehoboam loved Maachah the daughter of Absalom above all his wives and his concubines." In other words, she was the chief wife. The marriage is not specifically mentioned in Kings, but is implied thus : "And Rehoboam slept with his fathers . . And Abijam his son reigned in his stead... Three years reigned he in Jerusalem. And his mother's name was Maachah, the daughter of Abishalon."' From her position as chief wife of Rehoboam, Maachah would appear to be the heiress, deriving her rank from her mother Tamar. This position is confirmed by what follows : her son by Rehoboam, Abijam, succeeded to the throne, and was in his turn succeeded by Asa. "And Abijam slept with his fathers ... and Asa his son reigned in his stead ... And forty and one years reigned he in Jerusalem. And his mother's name was Maachah, the daughter of Abishalom."' Thus Maachah married first her cousin Rehoboam and then her own son Abijam. In II Chronicles xiii, 2, Abijam's mother is given as Michaiah the daughter of Uriel; but as the book of Kings is older and more authoritative than that of Chronicles, and as such consanguineous marriages were known among ancient nations who followed the custom of female inheritance, there is no reason to suppose that the more ancient record is wrong.

\footnotetext{
1 I Kings xiv, $31 ; x v, 2$.

2 I Kings xv, 8, 10.
} 


\section{The Roman Emperors.}

We turn now to the early emperors of Rome, from Julius Cesar to Nero. It is, I believe, acknowledged that matrilineal descent and female inheritance were the practice among the Roman kings, and I hope to prove that the custom was continued in the imperial line, and that the amazing matrimonial alliances in every degree of consanguinity, which have scandalised all historians from Suetonius down to the present day, were due not to vice but to political motives. There is no contemporary historian of this period, and when a chronicler did arise he was imbued with the ideas of male inheritance and patrilineal descent, and could not suppose that the haughty Claudians would follow any other custom, though he knew that they beyond all others clung to ancient custom and tradition.

As I have said before, kingship appears to depend on two things : (1) Appointment by the virtual ruler of the country, and (2) Marriage with the heiress. I think that this rule will be found to hold good, on the whole, among the early emperors. The appointment of his successor by the reigning monarch was called "adoption" by the Romans, and of these seven emperors, two only were not adopted: Julius Cæsar the founder of the empire, and Claudius, who was elected by the army. The adoption, however, does not appear to have been so important as the marriage; and in this paper I am dealing, with but few exceptions, with the legal and acknowledged marriages only.

There is another point in which the Roman emperors followed the custom of kings of other countries, and that was the claiming of divinity in their own persons. Thus in the three points-appointment, marriage, and divinity-the Roman emperors were precisely similar to the kings of earlier and often more barbarous times.

Julius Ccesar.-Julius Cæasar, as the founder of the imperial family, was possibly exempt from the rules of succession; but he was of royal blood through his paternal grandmother, who descended from Ancus Marcius, king of Rome; so that, to use Cæsar's own words, "Kings whose persons are sacred helped to make our family illustrious." His mother was Aurelia, daughter of Rutilia, and there the maternal line ends.

Augustus.-A Roman was free to adopt whom he pleased, but it is significant that Julius Cæsar followed the strict law of matrilineal descent. He adopted his sister's daughter's son, rather than his sister's son. The male ancestors of Augustus were of low extraction: his paternal great grandfather was said to be a manumitted slave and his father a money changer, while his mother's paternal grandfather was an African, either a perfumer or a baker [Suetonius]. This seems to me a clear case of rank descending in the female line, as Augustus never appears to have been considered as of inferior position.

By adoption-in other words, appointment by the reigning monarch-he was 


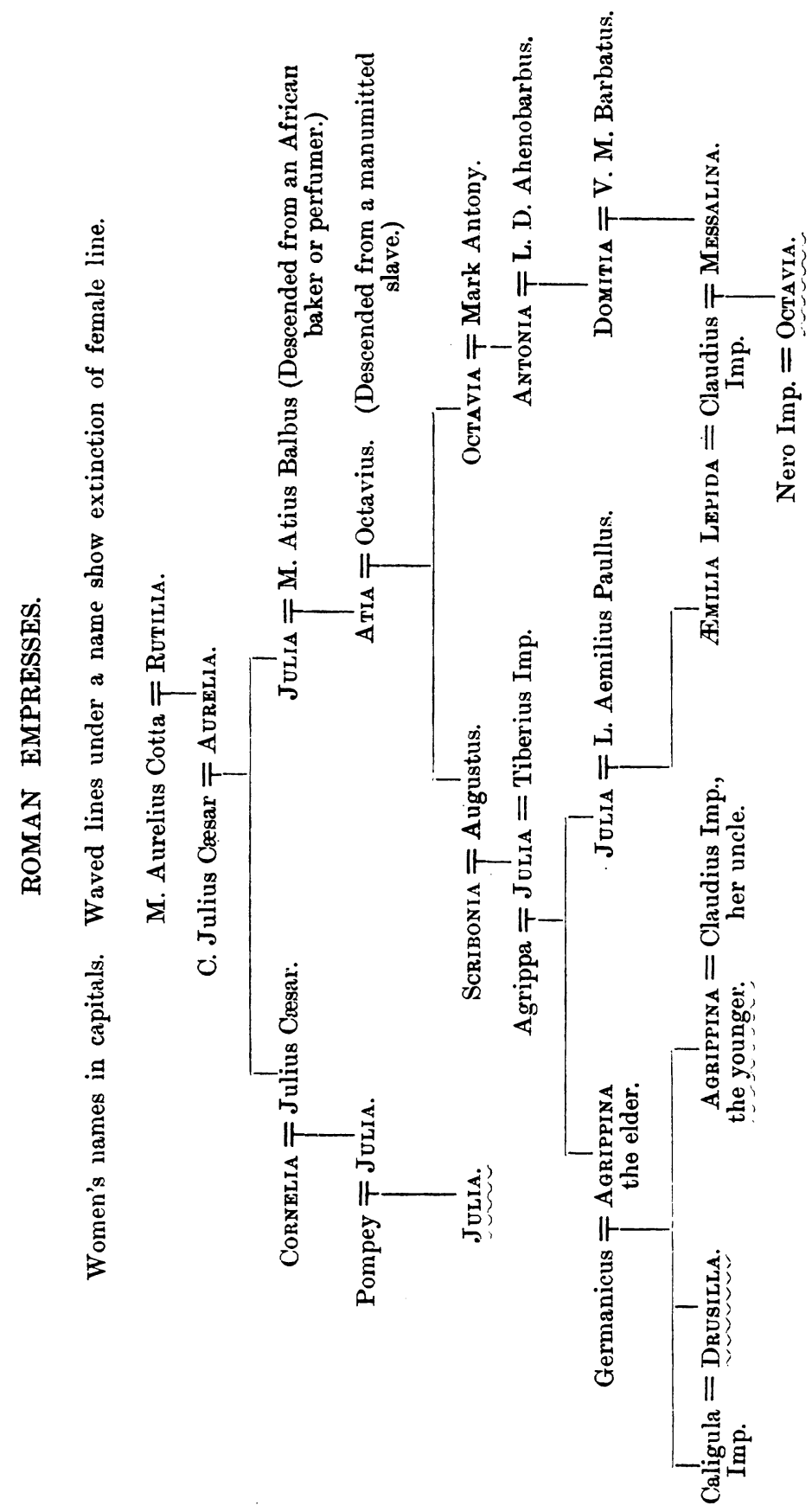


raised to the throne; and then comes the question of his marriages: He was married four times :-

1. Servilia, daughter of P. Servilius Isauricus. Before his adoption

2. Claudia, daughter of Fulvia and P. Clodius. Sent home.

3. Scribonia, already twice a widow. Divorced. One daughter.

4. Livia Drusilla, taken away from her husband.

The first two marriages were practically betrothals only, the interest lies in the third and fourth. And here I must confess myself at fault to a certain extent owing to the lack of particulars as to the descent of these two ladies; but judging by the analogies of other countries, Livia at least must have been in the direct female line of the royal house. Scribonia ${ }^{1}$ was divorced when she had borne a daughter, this daughter Julia being a most important person in the genealogies. Livia was taken away from her husband in a manner which reminds us of David's action when he claimed Michal from Phaltiel; Livia's husband, like Michal's, not objecting, in public at least, to what we, in the present day, would consider an intolerable outrage. The only explanation is that Augustus, having obtained the throne by appointment, legitimised his position completely by marriage. Livia had no daughters; and her line, according to matrilineal usage, ended with her. The Julian line continued through Octavia, the sister of Augustus, but the position of his daughter Julia can be accounted for only by seeing in her either the rightful heiress by descent through the mother from a royal ancestress, or the adopted heiress as in the case of the Ranis of Attingah. Whichever it may be, it is from these two women, Octavia and Julia, sister and daughter of Augustus, that the wives of the emperors and some of the emperors themselves descend.

To take Julia first. Her betrothals and marriages were :-

1. Antonius, son of Mark Antony.

2. Cotiso, king of the Getæ. $\}$ Betrothed.

3. Marcellus, son of Octavia.

4. Agrippa, already married to Octavia's daughter, Marcella.

5. Tiberius, after his adoption by Augustus.

She had five children by Agrippa, of whom two were daughters. But in this connection Caligula's statement must be remembered that his mother Agrippina was the daughter of Julia, not by Agrippa, but by her father Augustus; i.e., Agrippina was the offspring of a father-and-daughter marriage. If this were true, it would

${ }^{1}$ It is very remarkable that Scribonia should be divorced directly after the birth of her daughter. It is hardly possible that the sex of the child should be the reason; for if a son were absolutely necessary for the inheritance of the empire, the mere fact that Scribonia had already borne a child would be in her favour. But it is a possibility, which must be taken into account, that an heiress was required; and that having borne the heiress, Scribonia was no longer needed. In this connection it is worth noting that Poppæa Sabina received the title of Augusta as soon as she had borne a daughter. 
mean that Augustus, like the ancient Egyptian Pharaohs; made certain of the throne by marrying both the immediate heiress (in this case Livia) and the next in succession as well. The importance of the marriage of the heiress is shown by the law promulgated by Augustus, when punishing the lovers of the two Julias, his daughter and his granddaughter; of this law Tacitus' says: "By giving to a fault common between men and women the heinous name of treason and sacrilege, he departed from the lenity of his ancestors." In matrilineal countries, in earlier times, the man who was the de facto husband of the heiress, even though not so by law, had the right to the crown. The enactment of this law gives colour to the supposition that this was also originally the case in Rome itself. The laws against adultery in women, which were passed in the times of the earlier emperors, point to a state of society where the position of women, originally that of a matrilineal people, was steadily changing, inheritance passing into the male line and marriage laws becoming more stringent. Adultery in the case of an heiress belonging to a family which practised female inheritance was, under these circumstances, considerably more criminal than in the case of a less highly-placed woman, and the mere accusation of such a crime blasted her character more completely, for it threw doubt on the position both of her own husband and of the husband of her daughter. This also puts a more poignant meaning on the saying, "The wife of Cæsar must be above suspicion."

Tiberius.-If Livia carried the succession, as by her forced marriage with Augustus seems to have been the case, then her son, by whatever husband, would have the first claim on the throne and would be expected to marry the heiress. This is exactly what happened. Tiberius, Livia's eldest son, was adopted by Augustus, but-and this is an interesting point-he was already married to a woman of no particular rank, Vipsania Agrippina, by whom he had sons. His brother Drusus, however, had married the daughter of Octavia, whom I take to be also an heiress ; the sons of Drusus were therefore the rightful heirs, as obtaining the right through the mother. In no other way but that of matrilineal descent can one explain the adoption of the son of Drusus to the complete exclusion of the sons of Tiberius, about whose legitimacy there was no question. Tiberius was obliged to adopt Germanicus as his heir before he himself was adopted by Augustus; he had also to divorce his wife, to whom he was greatly attached, and marry the heiress Julia, who treated him with contempt as beneath her in rank. The senate appears to have been aware of the law of female inheritance, for they passed a decree that Tiberius should be officially styled the son of Livia as well as the son of Augustus.

It is in this reign that we see most clearly the struggle between the old order and the new; the haughty Claudian women fighting for their ancient rights, the dark and wily Tiberius taking advantage of every mistake of his adversaries, of every atom of his own power, to defeat them. Against his mother Livia he could

1 Tacitus, Annals, iii, 24. 
make no headway: she arrogated to herself the hereditary right to rule, and after a time he retired from the contest till her death. But his wife was practically imprisoned on charges of adultery, which according to Augustus's new law was treason; her daughter Julia was banished for the same reason; there remained only her other daughter Agrippina, against whom as the idol of the army no one dared to make any accusation. Yet even Tiberius could not altogether accept the idea of inheritance in the direct male line, for when the senate conferred honours on the two elder sons of Germanicus he administered a sharp rebuke, saying, "That no one should encourage the giddy minds of young men to indulge in presumptuous aspirations by premature distinctions."

Tiberius was persuaded that Agrippina had designs on the sovereignty, ${ }^{2}$ and after her husband's death he was adamant in his refusal to let her marry again. He so persecuted her that her proud spirit could endure no more, and she preferred death to life. By the death of Agrippina the succession was removed to the next generation; Agrippina's daughters were young enough to be kept in subjection, and Tiberius reigned in peace. Though he does not appear to have adopted Caligula legally, it is possible that the adoption of Germanicus, Caligula's father, would extend to the son, for Tiberius left all his property by will to be divided between Caligula and his own grandson.

Caligula.-Though Tiberius wished his own son to succeed him, he had no power to alter the regular succession, and the throne passed to the son of Agrippina. The heiresses were her daughters, Drusilla, Agrippina, and Julia. Here we are confronted with a condition of affairs which frequently occurred among matrilineal peoples, that the chief heiress was the sister of the principal male. The solution of the problem was the same here as in other places under similar conditions, the marriage of the brother and sister; Caligula and Drusilla were openly married. Caligula is also said to have intrigued with his other two sisters; in an earlier stage of society he would have married all three heiresses, but in monogamous Rome this was impossible, and though he secured his own position in the best way he could, he succeeded in scandalising all later historians. The great importance of the sisters is shown by his command that the army should swear allegiance to himself in the words : "Nor do I esteem myself nor my children more dearly than Cæsar and his sisters," and that the consuls should insert this phrase in all their public acts and reports: "Wishing all happiness to Caius Cæsar and his sisters" [Suetonius].

Caligula's marriages were :-

1. Junia Claudilla. Died. Before he had hope of succeeding.

2. Drusilla, his sister. Wife of L. C. Longinus. Died.

3. Livia Orestilla. Wife of C. Piso. Divorced.

4. Lollia Paulina. Wife of C. Memmius. Divorced.

5. Cesonia. Killed at the same time as Caligula.

1 Tacitus, Annals, iv, 17.

${ }^{2} I d . i b .$, iv, 12. 
The matrilineal descent of these ladies, with the exception of Drusilla, cannot be traced, but it is worth noting that three were taken away from their husbands and that Lollia Paulina was married to Caligula and twice married to Claudius, which argues that her position was of importance. Caligula's two younger sisters were banished, perhaps because public opinion refused to countenance further marriages within the family. Caligula had only one child, a daughter, who was killed at the same time as her parents. The succession thus remained with the banished sisters and with the descendants of Octavia.

Claudius.-Though the army took upon itself the right to choose the Emperor, it chose the man who, according to matrilineal descent, had the best claim, and whom Tiberius had indicated as his heir, ${ }^{1}$ viz., Claudius.

His marriages were :-

1. Atmilia Lepida. Divorced because her parents offended Augustus.

2. Livia Medullina, surnamed Camilla, descended from Camillus the Dictator. Died.

3. Plautia Urgulanilla. Divorced for adultery and suspicion of murder.

4. Elia Petina. Divorced for slight and trivial reasons.

5. Valeria Messalina. Killed.

6. Lollia Paulina. Twice married and divorced, then killed.

7. Agrippina the younger, his brother's daughter.

His children were :-

By Urgulanilla: Drusus and_Claudia.

By Petina : Antonia.

By Messalina: Octavia and Britannicus.

Of his children, Drusus the elder son never seems to have been considered as the future emperor, and Antonia and Claudia were apparently inferior to Octavia; a glance at the genealogies will show the reason for this preference for the children of Messalina.

The marriages of Claudius with Messalina and Agrippina are the most interesting, as each was the heiress of her respective line; Emilia Lepida was also of importance, as her genealogy shows, which was, perhaps, the reason why Augustus insisted on the divorce.

The circumstances surrounding the death of Messalina are only explainable by the custom of female inheritance and succession by right of marriage with the heiress. Agrippina and her sister being for the time under a cloud owing to their intrigue with Caligula, the heiress of the other line became prominent. Messalina's marriage with Silius was no hole-and-corner affair, but was open and public. Claudius himself signed the documents for the settlement of the dowry upon the contract of marriage. ${ }^{1}$ Tacitus says, "I am aware that it will appear

1 Suetonius. 
fabulous that ... in a city where everything was known and talked of, anyone, much less a consul elect, should have met the emperor's wife on a stated day in the presence of persons called in, to seal the deeds, as for the purpose of procreation, and that she should have heard the words of the augurs, entered the house of the husband, and sacrificed to the gods." In short, she appears to have legally married Silius, having previously legally divorced Claudius. Tacitus ends his description thus: "I would not dress up my narrative with fictions to give it an air of marvel rather than relate what has been stated to me or written by my seniors." Suetonius says of this affair that Claudius "slackened his burning affection for Messalina, not so much out of any resentment . . . as out of fear that she sought to advance Silius to the throne; at what time he fled in a most shameful and cowardly manner to the camp, solicitously enquiring all the way whether the empire was his or no." Tacitus says that Messalina took advantage of Claudius's absence to solemnise the marriage ; but his description of the care that was taken to break the news to the emperor cannot be reconciled with Suetonius's statement that Claudius was a party to the proceedings. What, perhaps, really caused Claudius's agitation was the result of the marriage, which Narcissus explained to him in unvarnished terms: "Know you, Cæsar, that you are in a state of divorce? in the face of the people, the senate, and soldiery, Messalina has espoused Silius; and unless you act with despatch, her husband is master of Rome," $[\mathrm{xi}, 30]$. 'It was then that Claudius asked whether he were still emperor, and Silius still a private citizen.

Callistus, one of the murderers of Caligula; Narcissus, who plotted the murder of Appius ; and Pallas, the reigning favourite, were the formidable trio who controlled Claudius at this juncture. They were, as their later conduct shows, in favour of the other matrilineal heiress, Agrippina, to whom Messalina, as the strictly legitimist heiress, had always been a relentless enemy; but that there was a party who held by Messalina we know by finding mention later in this reign of those who revered her memory. The ruthless advisers of Claudius prevailed, and Messalina was killed; then came the question of the emperor's re-marriage. Agrippina, of course, carried the day, and thenceforth she was empress in fact as well as in name, so much so that Tacitus-a great stickler for what our grandmothers called "female propriety"-is shocked at the way she arrogated to herself the functions and position of royalty, actually making herself equal with the emperor himself. She had no daughters, therefore the matrilineal succession on that side ended with her.

Nero.-We are again confronted with the fact that in the imperial family the son did not succeed the father. Claudius adopted his step-son and great-nephew Nero to the exclusion of his own son Britannicus. Though the later writers, imbued with the idea of patrilineal descent, try to explain the matter by saying that Nero succeeded because he was older [only two years as a matter of fact] and therefore fitter to take on the government than Britannicus, the fact remains that in the cases where the early emperors had sons, those sons were always set aside 
and another heir adopted, a condition of things impossible in a patrilineal people.

Nero's marriages were:-

1. Octavia. Married when Nero was about 16. Divorced and killed.

2. Agrippina [?]. Killed.

3. Poppæa Sabina, wife of Rufus Crispinus, then wife of Otho. Married 12 days after divorce of Octavia. Called Augusta after birth of daughter.

4. Statilia Messalina, wife of Alticus Vestinus, whom he put to death. Otho intended to marry her on Nero's death.

Agrippina continued to rule the empire at first, and during that time she is said to have carried on an intrigue with Nero. ${ }^{1}$ If this were true it would mean that Nero legitimised his position, like the ancient Pharaohs, by marrying all the heiresses without regard to degrees of affinity. But against this theory is the character of Agrippina herself ; Nero dared not marry her openly, and so proud and haughty a woman would not have consented to anything less than marriage. She leagued herself also with Octavia against their common enemy, Poppæa Sabina. Agrippina had no daughters, but there was always a possibility of her re-marriage, and therefore she was removed.

Poppæa's part in the tragedies of the Claudian house has been explained by her ambition to become empress. The methods she used were, to say the least, barbarous and clumsy : banishment for Agrippina and divorce for Octavia would have been sufficient to attain her end under ordinary circumstances, but when we see that the death of Agrippina ended the matrilineal line from Julia, daughter of Augustus, and the death of Octavia the direct matrilineal line from Octavia, sister of Augustus, it would appear that she desired not only advancement for herself but the extinction of all possible rivals. The re-marriage of Octavia was a great danger, as Poppæa pointed out to Nero, after the riots in favour of the banished Octavia had been calmed down: "The first commotion had subsided under moderate applications, but if they [the populace] should despair of Octavia's being the wife of Nero they would give her another husband." Octavia was accordingly recalled, accused of adultery - the usual charge brought against the heiress of the imperial family when in the way of those in power-and in consequence put to death.

With the deaths of Agrippina and Octavia the direct female lines came to an end, and the imperial crown passed to usurpers and finally to another family.

The genealogies of the mothers and wives of elaimants to the throne show that the claim was made on the basis of matrilineal descent and female inheritance.

1 Tacitus, Annals, xiv, 2.

I Id. $i b .$, xiv, 6. 


\section{CLAIMANTS TO THE IMPERIAL THRONE.}

Women's names in capitals. Claimants' names underlined.

I.

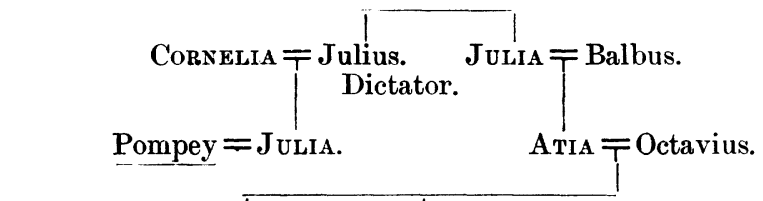

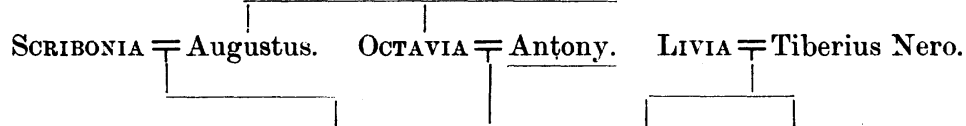

Agrippa $=$ Julia. Antonia $=$ Drusus. Tiberius = Vipsania Agrippiva.

L. Enilius Paullus =JuliA. AgriPPINA $=$ Germanicus. Imp.

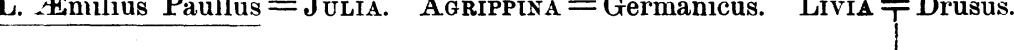 JoLIA $=$ Rubellius Blandus.
Rubellius Blandus.

II

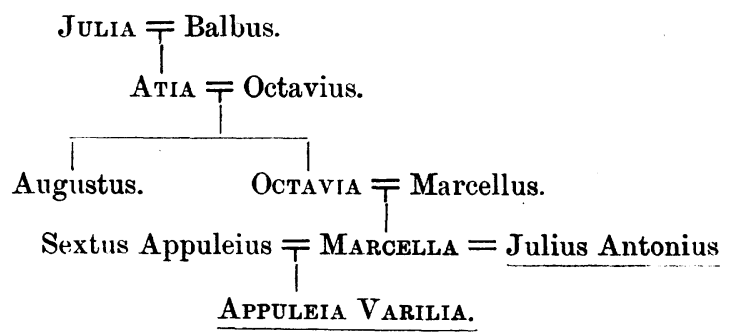

